\title{
PARADIGMAVÁLTÁS(OK) A HAZAI HUMÁN ÉS TÁRSADALOMTUDOMÁNYOKBAN A HATVANAS ÉS HETVENES ÉVEKBEN
}

„Korunk szellemi körképe” címet is adhatnánk e könyvismertetésnek, ha a Bollobás Enikő által szerkesztett kötet a hazai humán és társadalomtudományok mai panorámáját nyújtaná. Ám e tanulmánygyüjtemény nem a mai tudományosság térképét vázolja fel, még csak nem is a tegnapit, hanem voltaképpen a tegnapelőttit. A humán és társadalomtudományok különböző szakterületeinek mai képviselöi joggal fordítják tekintetüket a tudománytörténet irányába, miközben azt mutatják fel, hogy négy-öt évtizeddel ezelőtt az általuk múvelt diszciplínákban milyen változások következtek be. Az olvasó számára kiderül, hogy ezek a folyamatok egymáshoz meglepően hasonlóak voltak. A hatvanas-hetvenes években lezajlódó, sokat emlegetett paradigmaváltás a legtöbb tudományág esetében a korábbi diakrón módszerekkel szemben az elméleti-szinkron módszerekhez való fordulást jelentette. Az Elméletek vonzásában cím erotikától sem mentes konnotációja Roland Barthes The Pleasure of the Text címü, 1973-as könyvét is idézheti. De e vonzódás több mint alkalmi flört; az elmélet véglegesen kiszabadította a humán és társadalomtudományokat a marxista ideológia által determinált történetiség rabságából.

Elgondolkodtató a kötet címének második fele: a „»határtalan tudomány« kezdetei a hatvanas-hetvenes években". Két kérdést tehetünk fel: mit jelent az, hogy „határtalan” a tudomány, és mit jelent a „kezdetekre” való utalás? Az emberi tudás mindig határtalan volt, $\mathrm{s}$ a tudás, a scientia elválaszthatatlan volt a sapientiától, s az pedig a bölcsesség kezdetétől. Minden tudás tehát végeredményben „metatudás” is volt, hiszen önmagán túlmutatott. A határok ugyanakkor szükségszerű cölöpök a tudás végtelen tengerében. Szükségszerüek, mert a valóságról való emberi tudás (a tudomány) a tárgyának megismerése, majd autonómiájának elnyerése érdekében elkülönít és szétválaszt, majd kidolgozza saját módszertanát. Ám térségünkben a 20. század második felében a tudomány természetétől idegen „határzárat”, nevezetesen a marxista ideológia vasfüggönyét húzták fel. Nemcsak éveknek, hanem évtizedeknek kellett eltelniük ahhoz, hogy részint a külső geopolitikai klímaváltozás, részint a belső erjedés következtében a tudományok modern képviselői fokozatosan áttörjék a felülről jövő direktívák páncélkeménynek hitt falát. Amíg a politikai határzár nyitása csak 1989-90-ben történt meg, addig az értelmiség a maga eszközeivel már több évtizede dolgozott - eleinte kevesebb, 
majd egyre több sikerrel - azon, hogy a fullasztóan zárt tér köré felhúzott falakon rés támadjon.

Hét tudományterület egy-egy neves képviselője sokszor személyes tapasztalatokra is hivatkozva, ám az objektivitás igényével tekinti át, hogy saját tudományterületén miképpen zajlott le a paradigmaváltás a hatvanas és a hetvenes években. A kötet egyes tanulmányai többnyire tizenöt és huszonöt oldal között mozognak; van olyan tanulmány, amelyik harmincöt oldal terjedelmü, s olyan is, ami mindössze hat.

Kiefer Ferenc alapos tanulmánya a nyelvtudomány területén mutatja be az elméleti nyitás mozzanatait. A szerző egyaránt támaszkodik a hozzáférhető forrásokra és a személyes emlékeire. Hasznos áttekintést ad a modern nyelvtudomány születéséről, s a nyelvészeti strukturalizmus hazai kezdeteiről. A tanulmány rámutat, hogy a magyar strukturalizmus első képviselője Laziczius Gyula volt, aki számára 1938-ban alapították a világon első általános nyelvészeti tanszéket. A háború után a nyelvészetben zajlott le először a strukturalizmus-vita, Telegdy Zsigmond ismerte fel először Noam Chomsky jelentőségét. A strukturalista nyelvészetnek nemcsak a marxizmus, hanem történeti nyelvészet dominanciájával szemben is meg kellett küzdenie az autonómiáért. 1964-ben indulhatott az általános és alkalmazott nyelvészeti szak. A szerző rámutat, hogy a magyar nyelvtudomány a hetvenes évekre a térségünk vezető nyelvtudományává vált, hiszen a generatív nyelvészet is nálunk bontakozott ki.

Bernáth Árpád a hatvanas és a hetvenes évek irodalomelméleti paradigmaváltásának vajúdásait mutatja be annak a szegedi irodalomelméleti műhelynek a szemszögéből, amelynek a korán elhunyt Kanyó Zoltán volt a vezetője, s másik prominens tagja pedig ő maga volt. Innen indult Bonyhai Gábor, Masát András és Csúri Károly is. A Kanyó-Bernáth-Csúri vezette iskola később a „lehetséges világok" mühelyeként vált nemcsak országosan, hanem nemzetközileg is elismertté. A föleg germanista fiatal generáció Halász Előd tanítványainak sorából került ki, de Halász - föleg személyes tudományos kudarcai következtében - fokozatosan elhatárolódott saját tanítványaitól. Így nekik vagy ösztöndíjak, vagy aspirantúrák elnyerésével sikerült áttörniük a hatalmi struktúrák és a szakmai féltékenység falát. Vajda György Mihály komparatista professzor Szegedre kerülésével azonban szellemi védelmet kapott az ekkorra már nem is annyira fiatal kutatónemzedék.

Hankiss Elemérnek, majd Szegedy-Maszák Mihálynak a szegedi egyetemre kerülésével az anglisztika területén is innovatív kezdeményezések indulhattak. A marxista irodalomkritika egyeduralmát az orosz formalisták, a prágai iskola, majd az amerikai ,új kritika" irányzatainak megjelenése kezdte fokozatosan megtörni. Ezt mutatja be Bollobás Enikő Az elsö nyelvi fordulat Magyarországon-A strukturalista szemlélet megjelenése az irodalomtudományban címü tanulmánya. Az irányzat nyitányaként Ferdinand de Saussure híres munkájának 1967-es magyar nyelvü megjelenését tekinthetjük, s ezt hamarosan követte 
Hankiss Elemér kétkötetes Strukturalizmus címü tanulmánygyüjteménye, majd Roman Jakobson, René Wellek, Austin Warren, Jurij Lotman, Vlagyimir Propp, Umberto Eco, Viktor Zsirmunszkij és mások könyveinek magyar kiadása. Tanulmánya második felében Bollobás szemléletesen mutatja be a hetvenes évek végének ,strukturalizmus-vitáját”, amely arról szólt, hogy a marxizmus befogadhatja-e a strukturalista szemléletet. A strukturalisa módszer lényegét Bollobás négy pontban summázza: a bináris kategóriák fellelése, a szinkron megközelítés, az interdiszciplinaritás s végül a szöveg szerves egészének, autonómiájának hangsúlyozása. Ugyanakkor - s ez Bollobás tanulmányának tézise: a strukturalizmus megjelenése még nem tekinthető igazán paradigmaváltásnak, hanem csak „első, gyenge nyelvi fordulatnak” az irodalomtudományban. Csupán a „második, erős nyelvi fordulat", a nyolcvanas évek elején megjelenő, a világképelemzést is integráló gadameri hermeneutika, jaussi recepcióesztétika, a derridai dekonstrukció vagy a lacani pszichoanalízis hazai felfedezése jelent igazi paradigmaváltást.

Czigler István Agy és elme: szerencsés találkozások címü írásában a hazai kognitív pszichológia kibontakozását mutatja be. Kardos Lajos már nemcsak a pavlovi irányra, hanem az Edward Tolman nevéhez köthető „,neobehaviorizmus” elméletére is támaszkodik az állati emlékezés vizsgálatában. A neobehaviorizmus arra épül, hogy vizsgálni kell, mi van a viselkedést megindító környezet és a nyílt viselkedés között. Az agy egyes területeinek instrumentális kondicionálására vonatkozó új kutatásokhoz Grastyán János és Ádám György csatlakoztak. Humán kognitív pszichológiai kutatásokat Marton Magda végzett. Az elvont fogalmak mögötti mozgástendenciákat Putnoky Jenő a fogalomalkotás szempontjából vizsgálta. Ehhez kapcsolódtak az irodalomszociológia oldaláról Erős Ferenc, a szociálpszichológia oldaláról pedig Hunyady György kutatásai. Döntő áttörést Pléh Csaba munkássága jelentett, aki sikeresen kapcsolta össze a kognitív pszichológiát a nyelvészettel.

Újabb határátlépő diszciplína a pszichológiát és a szociológiát összekötő szociálpszichológia, amely - már Hunyady György tanulmányának címe alapján is olyan tudomány, amely elvesztette a „burzsoá áltudomány” jellegét. Buda Béla, Mérei Ferenc, Pataki Ferenc, Garai László vagy Hunyady György a hatvanas évek végétől kezdve egyre élénkebb kapcsolatot építettek ki külföldi kollégáikkal, s itthoni tanulmányaik fóruma a Valóság címü folyóirat lett. Pataki Ferenc munkássága adott újabb lendületet a szociálpszichológiai kutatások számára, az ő vezetésével indulhatott meg az egyetemi szociálpszichológiai képzés. Hunyady Györgynek ugyancsak ellenszélben kellett megvédenie az 1972-ben a szociálpszichológia területén elsőként beadott kandidátusi értekezését. Pataki Ferenc munkásságának is komoly ellenálláson kellett átvergődnie, míg végül eljuthatott az akadémikusságig, s ezáltal a diszciplína elismertségét is elérte.

Sajnáljuk, hogy Romsics Ignácnak A magyar történetírás megújulása a Kádár-korszakban címủ írása nem lépi túl az eredeti előadás szigorú időkorlátait, $\mathrm{s}$ 
így csupán hat oldalban kaphatunk képet egy klasszikus régi diszciplína, a történetírás 1956 utáni válságáról, majd megújulásáról. A háború utáni történetírás hírhedt moszkvai helytartói a magyar történelem egyoldalúan Habsburg-ellenes vonulatát és a Horthy-korszak fasiszta jellegét hangsúlyozták, s a marxista üdvtörténettel helyettesítették a szaktudományt. Az igazán nagyformátumú óriások Nyugatra távoztak, kényszernyugdíjba kerültek, mint Mályusz Elemér, sokáig a perifériára szorultak, mint Kosáry Domokos, Benda Kálmán vagy Szücs Jenő. A Kádár-korszak második felében azonban fokozatosan liberalizálódhatott az addig szoros ideológiai gyeplön tartott történetírás. Ebben a folyamatban elévülhetetlen érdemei vannak a korán elhunyt Ránki György akadémikusnak, akinek irányítása alatt megindulhattak a gazdaságtörténeti kutatások, s teret nyerhettek a francia Annales-kör hatására kialakult mentalitástörténeti kutatások is.

A tanulmánykötet utolsó írása Bayer József tollából való, aki a politikatudomány kialakulásáról ír A megosztott diszciplina - Iskolák és szekták a politikatudományban címen. Rámutat, hogy e tudomány fokozatos önállósodása a nyolcvanas évekre tehető, igazán csak a rendszerváltozás után került be a felsőoktatásba. A szerző az egyes politikaelméleti iskolákat Gabriel A. Almond-t követve négyes mátrixban helyezi el, megkülönböztetve a „soft right”, „hard right”, illetve a „soft left”, „hard left” irányzatokat. Bayer az alábbi iskolákat mutatja be: az új institucionalizmus, a behaviorizmus, a racionális választás elmélete és a konstruktivizmus. A Politikatudományi Szemle a rendszerváltozás utáni években főleg az ideológiák és a hatalmi szerkezetek, a pártok, a választások kérdéseivel foglalkozik. Ám idehaza - zárja a tanulmányát Bayer József - még hiányoznak a markáns tudományos iskolák.

Az Elméletek vonzásában címü kötet a két nemzedékkel ezelőtti, „tegnapelőtti” szellemi áttörésről szól, ami egy nemzedékkel korábban zajlott le, mint a politikai rendszerváltozás. Az Elméletek vonzásában azonban nemcsak tudománytörténeti kuriózum, hanem egyúttal aktuális mementó is lett, hiszen a tudomány ismét defenzívába kényszerült a hatalommal szemben. A könyv tehát a jelennek is szóló példa: a harcunkat nekünk is, itt és most, ugyanúgy meg kell vívni, abban a biztos reményben, hogy a szellem legfeljebb megalázható, véglegesen nem pusztítható el.

(Bollobás Enikö szerk.: Elméletek vonzásában. A „határtalan tudomány” kezdetei a hatvanas-hetvenes évek humán és társadalomtudományi kutatásaiban. Budapest: Gondolat, 2019, 248 o.)

Fabiny Tibor

irodalomtörténész, egyetemi tanár Károli Gáspár Református Egyetem 